\title{
Effect of heat treatment on the tensile properties of incrementally processed modified polylactide
}

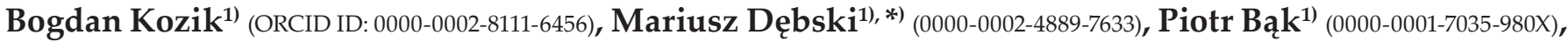 \\ Małgorzata Gontarz ${ }^{1)}$ (0000-0002-1803-4415), Małgorzata Zaborniak ${ }^{1)}$ (0000-0002-3219-3092)
}

DOI: dx.doi.org/10.14314/polimery.2021.6.4

\begin{abstract}
The influence of temperature $\left(80,95\right.$ and $\left.110^{\circ} \mathrm{C}\right)$ and annealing time (20, 25, $\left.30 \mathrm{~min}\right)$ on the tensile strength and elongation at break of the modified polylactide (PLA Pro) processed by 3D printing (FFF - Fused Filament Fabrication) was investigated. The properties of PLA Pro were compared with properties of unmodified PLA and ABS. It was observed that the tensile strength was comparable for all annealed samples and was about $45 \mathrm{MPa}$. Moreover, the annealing process decreased the tensile strength of the modified PLA and increased the elongation at break, which may be related to a change in the degree of crystallinity. The modified PLA was characterized by tensile properties similar to ABS.

Keywords: polylactide, heat treatment, tensile properties, additive manufacturing.

\section{Wpływ obróbki cieplnej na właściwości mechaniczne przy rozciąganiu modyfikowanego polilaktydu przetwarzanego przyrostowo}

Streszczenie: Zbadano wpływ temperatury $\left(80,95\right.$ i $\left.110^{\circ} \mathrm{C}\right)$ i czasu wygrzewania $(20,25,30 \mathrm{~min})$ na wytrzymałość na rozciąganie i wydłużenie względne przy zerwaniu modyfikowanego polilaktydu (PLA Pro) przetwarzanego metodą druku 3D (FFF - Fused Filament Fabrication). Właściwości PLA Pro porównano z właściwościami niemodyfikowanego PLA i ABS. Zaobserwowano, że wytrzymałość na rozciąganie była porównywalna dla wszystkich próbek i wynosiła około $45 \mathrm{MPa}$. Ponadto, proces wygrzewania spowodował zmniejszenie wytrzymałości na rozciąganie modyfikowanego PLA i zwiększył wydłużenie przy zerwaniu, co może być związane ze zmianą stopnia krystaliczności. Modyfikowany PLA charakteryzował się właściwościami mechanicznymi przy rozciąganiu podobnymi do ABS.
\end{abstract}

Słowa kluczowe: polilaktyd, obróbka cieplna, właściwości mechaniczne przy rozciąganiu, technologie przyrostowe.

The dynamic development of additive manufacturing techniques (3D printing) results in the development of new methods, equipment solutions and model materials. Thus, the scope of application of additive techniques in various industries, medicine, architecture, aviation, etc. is widening [1-8]. One of the most popular additive manufacturing methods used to manufacture machine parts or prototypes is the FDM / FFF / MEM method (FDM - Fused Deposition Modeling/FFF - Fused Filament Fabrication/MEM - Melted and Extruded Modeling). It consists in feeding the polymer material to the heated nozzle (up to the temperature depending on the type of material used), which is then transferred to the working platform in a semi-liquid form. This method makes it possible to obtain compli-

\footnotetext{
1) Department of Machine Design, The Faculty of Mechanical Engineering and Aeronautics, Rzeszow University of Technology, Al. Powstańców Warszawy 12, 35-959 Rzeszów, Poland

*) Author for correspondence: m.debski@prz.edu.pl
}

cated elements that are uneconomical or impossible to produce with other methods [8].

Depending on the technical parameters of 3D printing, the model material and technical parameters, the mechanical and physical properties of a manufactured part will be different. Optional possibilities of improving the results of thermoplastic tests is the use of technical conditions - annealing. This process is widely used in the production of elements made of metal alloys and in the molding technology [10-12].

The materials used in the FFF technology are polymers, which means that they consist of repeating molecular chains. The molecular structure of polymeric materials can be divided into amorphous and semi-crystalline (partially ordered) $[13,14]$. In the annealing process of thermoplastic materials, the molecules reorganize their structure to the conditions of equilibrium and reducing internal stresses. This means that as a result of thermal treatment of polymeric materials, the amount of the crystalline phase increases [15-18]. 
The aim of this work was to investigate the effect of temperature $\left(80,95\right.$ and $\left.110^{\circ} \mathrm{C}\right)$ and annealing time (20, $25,30 \mathrm{~min}$ ) on the tensile strength and elongation at break of modified polylactide (PLA Pro) processed by 3D printing (FFF - Fused Filament Fabrication). The manufacturer of modified PLA Pro filament declares an increase in impact strength and a combination of the advantages of unmodified PLA and ABS due to the structure orientation. The change from amorphous to partially crystalline structure can only occur in the glass transition temperature range, which in the case of PLA ranges from 65 to $170^{\circ} \mathrm{C}$. This range is too wide to define favorable temperature useful in processing of aliphatic polyesters. Too high temperature will cause warping and shrinking of the printout [19]. Therefore, the tensile properties for PLA Pro were compared with unmodified PLA and ABS.

\section{EXPERIMENTAL PART}

\section{Materials}

Modified polylactide with the trade name PLA Pro produced by Spectrum Filaments was used. The reference samples were made of acrylonitrile-butadiene-styrene (ABS) copolymer and unmodified polylactide of the same company. The basic parameters of the used filaments are presented in Table 1.

$\mathrm{T}$ a b 1 e 1. Basic parameters of used filaments

\begin{tabular}{l|c|c|c}
\hline \multicolumn{1}{c|}{ Parameter } & PLA Pro & PLA & ABS \\
\hline Diameter, mm & \multicolumn{3}{|c}{$1,75 \pm 0,05$} \\
\hline $\begin{array}{l}\text { Printing } \\
\text { temperature, }{ }^{\circ} \mathrm{C}\end{array}$ & $185-230$ & $185-215$ & $220-270$ \\
\hline
\end{tabular}

\section{Samples preparation}

The samples were obtained in the FFF technology using the Prusa i3 MK3 3D printer. The sample model was created in the Inventor Professional environment and then saved to STL format. The paths were generated using software dedicated to the printing device. The universal type 1A sample was used for static tensile tests in accordance with PN-EN ISO 527-2.

Two batches of samples (one of them was intended for heat treatment) were obtained with the following fixed print parameters:

- Filling density of the internal structure - 100\%,

- 2 contour outlines,

- thickness of the polymer layer $0.15 \mathrm{~mm}$,

- alternating track system with angles of $45^{\circ}$ and $135^{\circ}$

Printing parameters for used filaments are presented in Table 2. It can be seen that 3D printing process parameters for polylactide and ABS are different.

The fittings made of PLA Pro have undergone heat treatment in order to change the structure of the material from amorphous to partially crystalline. The anneal-
T a b l e 2. Printing parameters for used filaments

\begin{tabular}{l|c|c}
\hline \multicolumn{1}{c|}{ Parameter } & PLA (PLA Pro) & ABS \\
\hline Die temperature, ${ }^{\circ} \mathrm{C}$ & 210 & 255 \\
Work table temperature, ${ }^{\circ} \mathrm{C}$ & 60 & 100 \\
Chamber & Open & Close \\
\hline
\end{tabular}

ing process was carried out for three different temperature $(\mathrm{T})$ and three different annealing time $(\mathrm{t})$, the values of which are presented in Table 3. A set of 5 samples was made for each configuration.

$\mathrm{T}$ a $\mathrm{b} 1 \mathrm{e}$ 3. Parameters of the annealing process of the tested materials

\begin{tabular}{c|c|c}
\hline $\begin{array}{c}\text { Parameter } \\
\text { configuration }\end{array}$ & Temperature, ${ }^{\circ} \mathrm{C}$ & Time, min \\
\hline 1 & & 20 \\
2 & 80 & 25 \\
3 & & 30 \\
\hline 4 & & 20 \\
5 & 95 & 25 \\
6 & & 30 \\
\hline 7 & & 20 \\
8 & 110 & 25 \\
9 & & 30 \\
\hline
\end{tabular}

\section{Methods of testing}

The tensile strength and elongation at break were determined using the INSTRON 5967 testing machine in accordance with PN-EN ISO 527-2 standard.

\section{RESULTS AND DISCUSSIONS}

It is well known that PLA is brittle polymer with tensile strength about $60 \mathrm{MPa}$ and elongation at break about $3 \%$. Whereas, ABS filaments show a clear yield point (45 MPa) with elongation at break about $4 \%$.

The dependence of tensile strength and elongation at break in relation to reference materials (PLA, ABS) as a function of heat treatment temperature are presented in Figures 1-6. Figures 7-12 show the dependence of tensile strength and elongation at break as a function of annealing time.

It can be seen that the tensile strength of the modified polylactide annealed at $80^{\circ} \mathrm{C}$ for 20,25 and 30 minutes was comparable to the ABS copolymer. The difference in tensile strength and elongation at break was less than $3 \%$ in relation to ABS. Modification of PLA influence the change of tensile properties, resulting in an increase in elongation at break. It is directly related to the decrease in tensile strength. In the case of PLA Pro, an increase in elongation of $35 \%$ and a $27 \%$ decrease in tensile strength compared to the unmodified PLA can be observed. 
In the case of samples annealed at the temperature of $95^{\circ} \mathrm{C}$ and $110^{\circ} \mathrm{C}$, it can be seen that the change of the temperature did not affect the value of the obtained results.

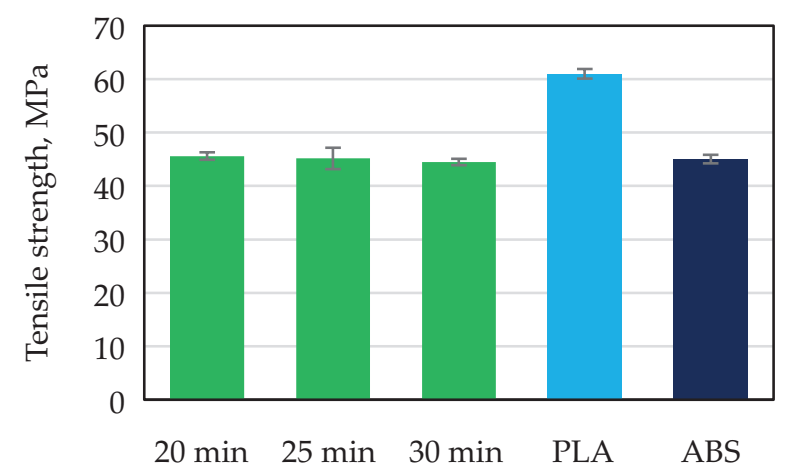

Fig. 1. Tensile strength at annealing temperature of $80^{\circ} \mathrm{C}$

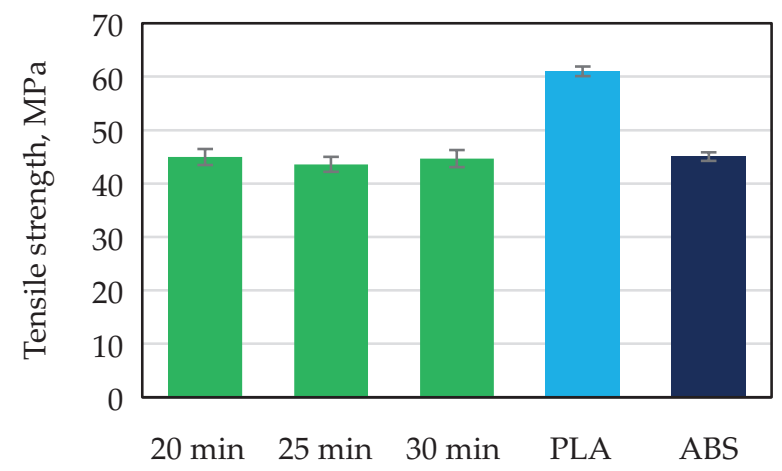

Fig. 3. Tensile strength at annealing temperature of $95^{\circ} \mathrm{C}$

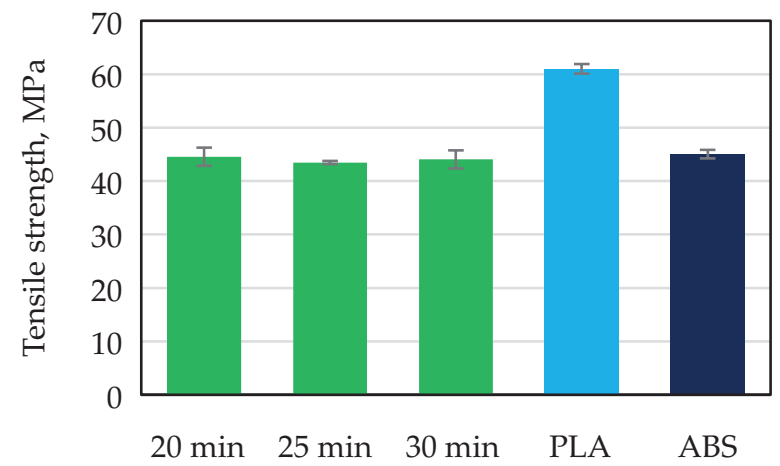

Fig. 5. Tensile strength at annealing temperature of $110^{\circ} \mathrm{C}$

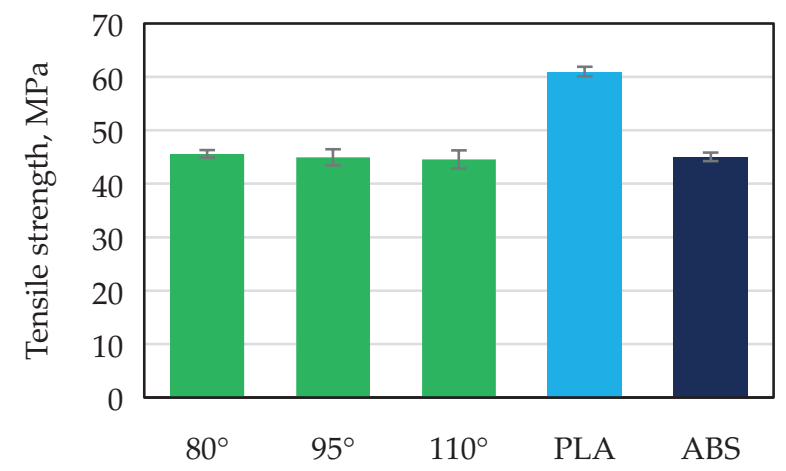

Fig. 7. Tensile strength during annealing time of 20 minutes
The PLA Pro was characterized by a tensile strength of about $45 \mathrm{MPa}$. Compared to the unmodified PLA, the elongation at break of the PLA Pro increased by $30-35 \%$.

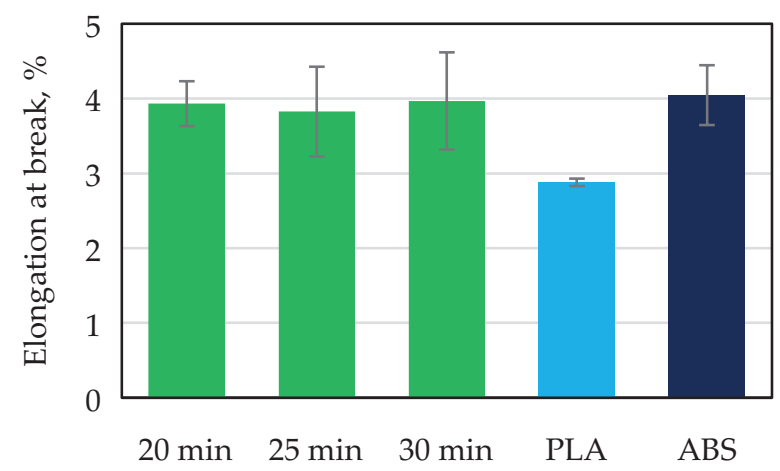

Fig. 2. Elongation at break in annealing temperature of $80^{\circ} \mathrm{C}$

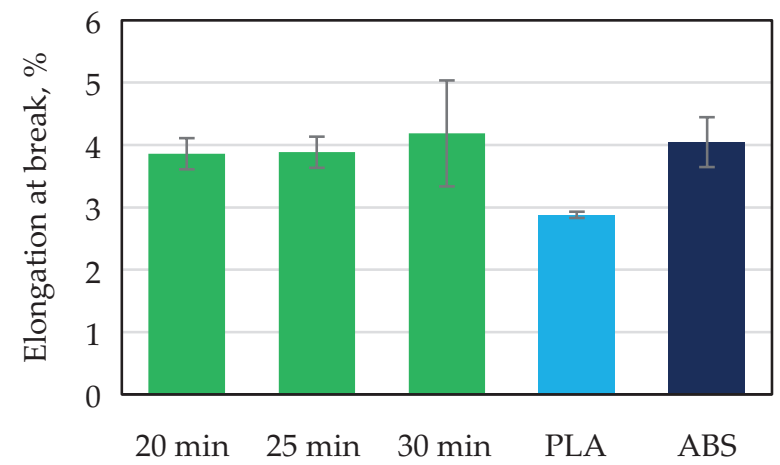

Fig. 4. Elongation at break at annealing temperature of $95^{\circ} \mathrm{C}$

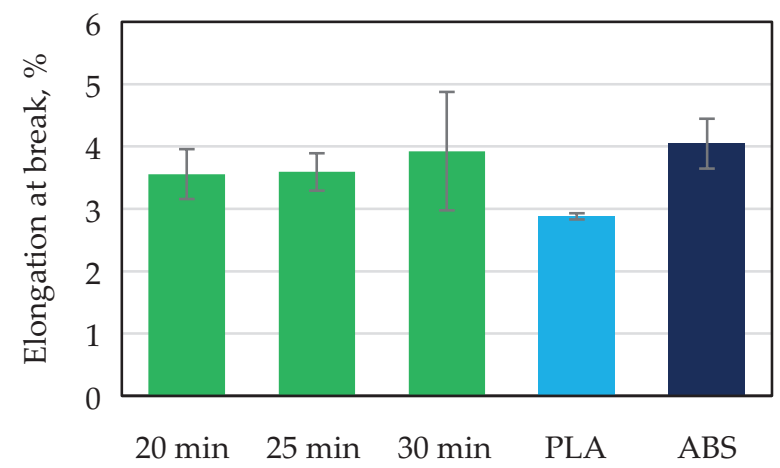

Fig. 6. Elongation at break at annealing temperature of $110^{\circ} \mathrm{C}$

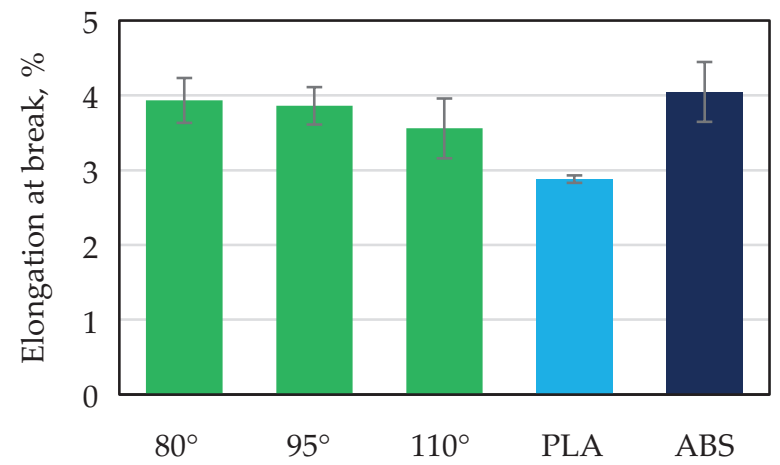

Fig. 8. Elongation at break during annealing time of 20 minutes 


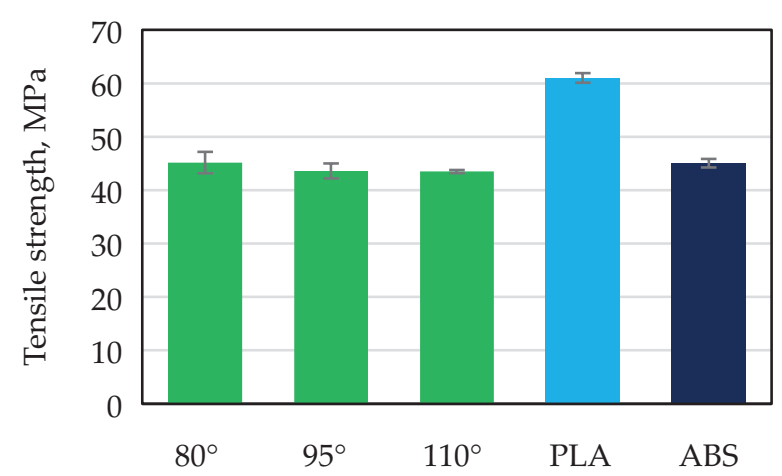

Fig. 9. Tensile strength during annealing time of 25 minutes

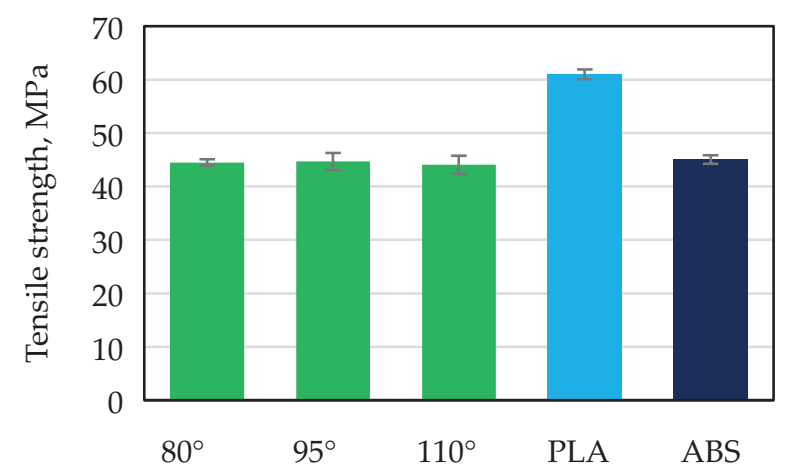

Fig. 11. Tensile strength during annealing time of 30 minutes

\section{CONCLUSIONS}

The modification of PLA significantly changed the tensile properties as evidenced by the lower tensile strength and higher elongation at break, which may be associated with a change in the degree of crystallinity. The tensile properties of modified PLA slightly depend on the heat treatment temperature and annealing time. However, lower temperature and shorter annealing time are more advantageous due to the smaller warpage and shrinkage. Moreover, the modified PLA was characterized by tensile properties similar to that of the ABS. An increase in adhesion of the samples to the working platform was also observed and the surface was more opaque than that for unmodified PLA.

\section{REFERENCES}

[1] Gisario A., Kazarian M., Martina F. et al.: Journal of Manufacturing Systems 2019, 53, 124. https://dx.doi.org/10.1016/j.jmsy.2019.08.005

[2] Budzik G., Magniszewski M., Przeszłowski Ł. et al.: Polimery 2018, 63, 830. https://doi.org/10.14314/polimery.2018.11.13

[3] Elakkad A.S.: International Journal of Engineering and Technical Research 2019, 8, 248. https://doi.org/10.17577/IJERTV8IS110122.

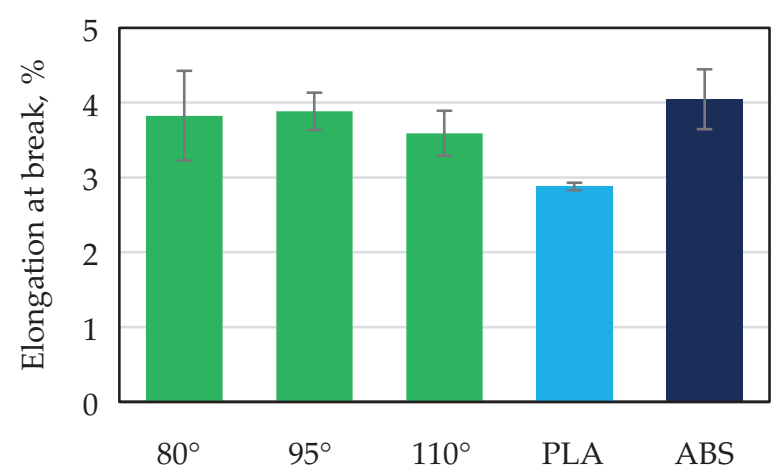

Fig. 10. Elongation at break during annealing time of 25 minutes

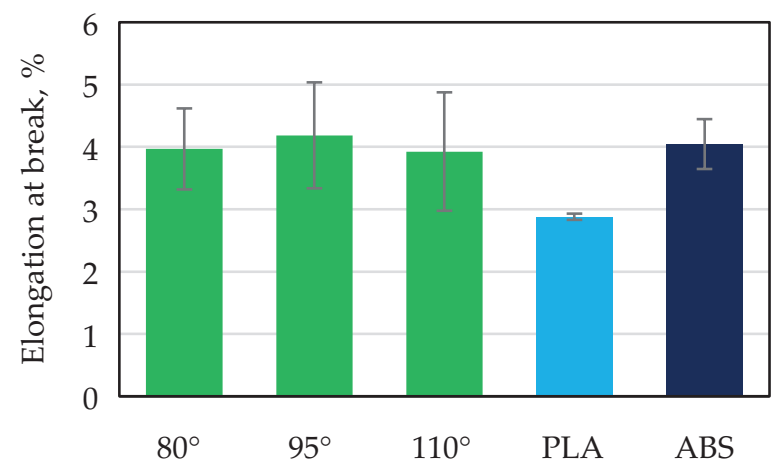

Fig. 12. Elongation at break during annealing time of 30 minutes

[4] Yoo S.Y., Kim S.K., Heo S.J. et al.: Materials (Basel) 2021, 14, 1550. https://dx.doi.org/10.3390/ma14061550.

[5] Budzik G., Markowski T., Oleksy M.: Modelowanie Inżynierskie 2009, 6 (37), 41.

[6] Mydłowska K., Tartakowski Z.: Przetwórstwo Tworzyw 2015, 21 (6), 467.

[7] Oleksy M., Budzik G., Heneczkowski M.: Polimery 2010, 55, 403.

[8] Oleksy M., Budzik G., Kozik B. et al.: Polimery 2017, $62,3$.

https://doi.org/10.14314/polimery.2017.003

[9] Budzik G., Siemiński P.: „Techniki przyrostowe”, Oficyna Wydawnicza Politechniki Warszawskiej, Warszawa 2015.

[10] Aly A.: Heat Treatment of Polymers: A Review, American Institute of Science, 2015.

[11] Migliore N., Polgar L.M., Araya-Hermosilla R. et al.: Polymers 2018, 10, 618. https://doi.org/10.3390/polym10060618

[12] Shah M.I., Yang Z., Li Y. et al.: Polymers 2017, 9, 559. https://doi.org/10.3390/polym9110559

[13] Rabek J.: „Polimery. Otrzymywanie, metody badawcze, zastosowanie", Wydawnictwo Naukowe PWN, Warszawa 2013.

[14] Gruin I.: „Materiały polimerowe”, Wydawnictwo Naukowe PWN, Warszawa 2003. 
[15] Grinyaev Y., Chertova N., Shilko E. et al.: Polymers 2018, 10, 1155. https://doi.org/10.3390/polym10101155

[16] Kelar K., Mencel K.: Przetwórstwo Tworzyw 2014, 20, 405.

[17] Geng P., Zhao J., Wu W. et al.: Polymers 2018, 10, 875. https://doi.org/10.3390/polym10080875
[18] Xie S., Zhang S., Wang F. et al.: Polymer Engineering and Science 2005, 45, 1247.

https://doi.org/10.1002/pen.20359

[19] Kelar K.: „Modyfikacja polimerów”, Wydawnictwo Politechniki Poznańskiej, Poznań 1992.

Received 14 V 2021.

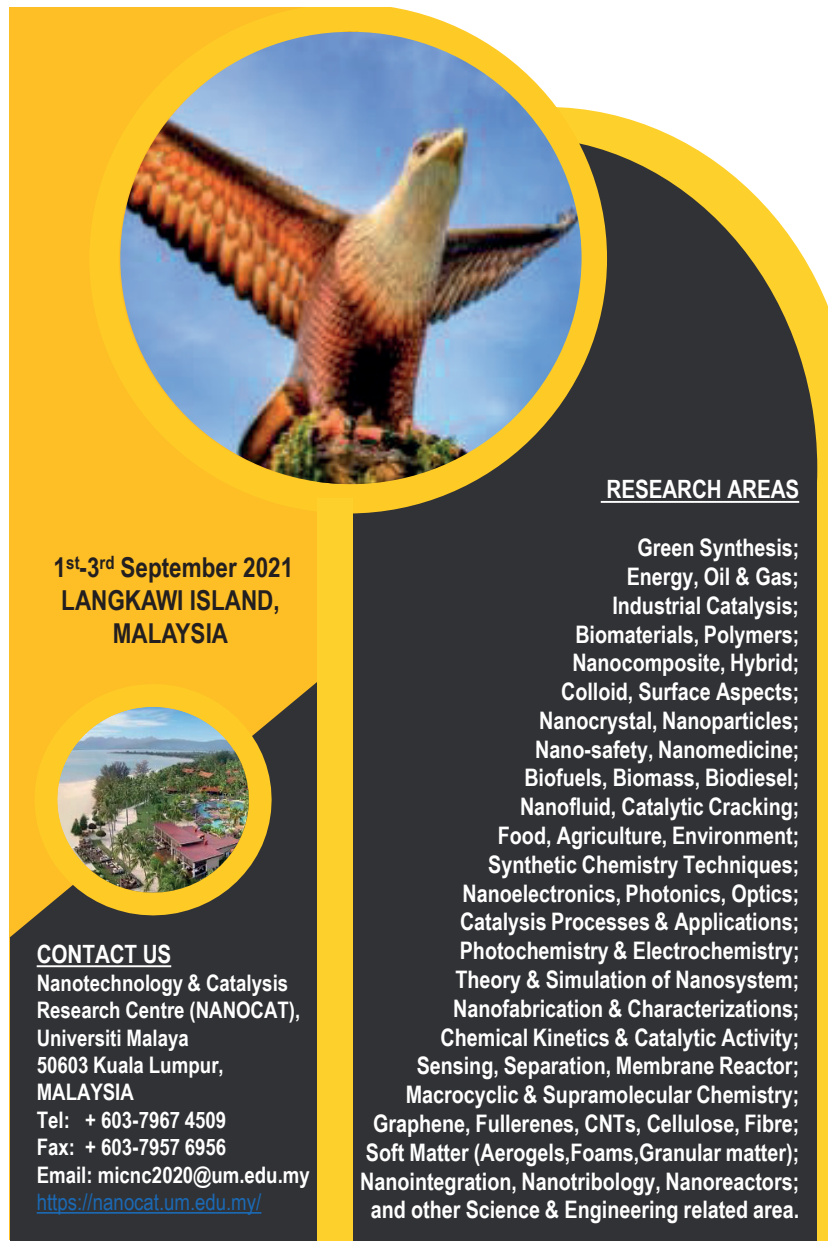

UNIVERITI

M A L A Y A
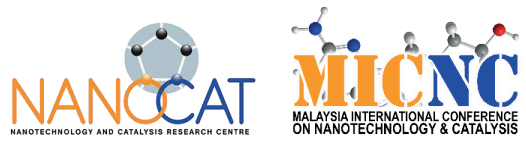

\section{I ${ }^{\text {st }}$ MALAYSI INTERNATIONAL CONFERENCE ON NANOTECHNOLOGY \& CATALYSIS $\Lambda$ NEW DAWN OF INNOV $T$ TION \& TECHNOLOGY}

The $1^{\text {st }}$ Malaysia International Conference on Nanotechnology \& Catalysis (MICNC2021) will be held on $1^{\text {st }} 3^{\text {rd }}$ September 2021 at Langkawi Island, Malaysia. The conference is hosted by Nanotechnology \& Catalysis Research Centre (NANOCAT), Universiti Malaya. MICNC2020 will be a great platform for researchers, academics, students as well as practitioners from industries to engage in knowledge and technology sharing. This conference also encourages participants to exchange experiences and challenges independently. Besides, it promotes future collaborations and knowledge transfer between participants. It includes plenary, keynote \& invited speakers, oral, virtual presentations \& poster sessions on different topics. All accepted full papers will be published in Clarivateindexed (ISI) journals. Award: Best oral and poster will be awarded.

Registration: https://umevent.um.edu.my/MICNC2021

\section{https://forms.gle/9T27uNC2LFgTG6u3A}

\begin{tabular}{|c|c|c|c|c|}
\hline $28^{\text {th }}$ FEB 2021 & th $^{\text {th }}$ APR 2021 & \multicolumn{2}{|c|}{$30^{\text {th }}$ MAY 2021} & $30^{\text {th }}$ JUNE 2021 \\
\hline $\begin{array}{l}\text { Deadline of } \\
\text { Abstract } \\
\text { Submission }\end{array}$ & $\begin{array}{l}\text { Early Bird } \\
\text { Registration } \\
\text { Deadline }\end{array}$ & $\begin{array}{c}\text { Dea } \\
\text { Fu }\end{array}$ & $\begin{array}{l}\text { e for } \\
\text { per }\end{array}$ & $\begin{array}{l}\text { Notification } \\
\text { of Full Paper } \\
\text { Acceptance }\end{array}$ \\
\hline \multirow{2}{*}{ Categor } & & \multicolumn{2}{|c|}{ Presenter } & Particinant \\
\hline & & Non-student & Student & \\
\hline \multirow{2}{*}{ Early registration } & Local & RM1300 & RM1000 & RM800 \\
\hline & International & USD400 & USD300 & USD250 \\
\hline \multirow{2}{*}{ Normal registration } & Local & RM1400 & RM1100 & RM900 \\
\hline & International & USD500 & USD400 & USD350 \\
\hline
\end{tabular}

*Group discount: A. 2-3 person, 10\%; B. 4-5 person, 15\%; C. more than 5, $20 \%$. $* 40 \%$ off for virtual presentation 